\title{
The Livelihood Challenge of Forest Honey Bee Farmers amidst COVID-19 Pandemic in Mutis, Indonesia
}

\author{
Gerson N. Njurumana ${ }^{1 *}$, Norman P.L.B. Riwu Kaho ${ }^{2}$, Elisa Iswandono ${ }^{3}$, Sherley S. Wila Huky ${ }^{4}$, \\ Budy Z. Mooy ${ }^{5}$, Fatmawati Fatmawati ${ }^{5}$, Darius A. Kian ${ }^{2}$, Yeni F. Nomeni ${ }^{6}$ \\ ${ }^{1}$ Environment and Forestry Research and Development Institute of Kupang, Nusa Tenggara Timur, \\ Indonesia. \\ 2 Nusa Cendana University, Kupang, Nusa Tenggara Timur, Indonesia. \\ ${ }^{3}$ Natural Resources Conservation Institute of Nusa Tenggara Timur, Indonesia. \\ ${ }^{4}$ Planning, Development and Reseacrh Agency of Nusa Tenggara Timur, Indonesia. \\ ${ }^{5}$ Environment and Forestry Education Training Institute of Kupang, Nusa Tenggara Timur, Indonesia. \\ ${ }^{6}$ WWF Nusa Tenggara and Director of Madu Mutis Centre, Nusa Tenggara Timur, Indonesia. \\ * Correspondence author: njurumana@gmail.com; Tel.: +62-081333702345
}

\begin{abstract}
The COVID-19 pandemic has affected various sectors of the global communities, including those that depend on forests for honey products. Furthermore, the dynamics of production and availability are completely affected by government restrictions. This study focuses on the short-term effects of the COVID19 pandemic on the forestry sector. Specifically, it examines the pandemic effect on forest honey farmers in habitat management, harvesting, marketing, farmer institutions, and livelihoods. The study was conducted on forest honey bee farmers through field observations and structured and in-depth interviews. Data were collected using five variables and 30 indicators in Fatumnasi Subdistrict, South Central Timor Regency and analyzed using descriptive and quantitative analysis. The results showed that the COVID-19 pandemic has changed the socio-cultural and economic utilization of forest honey. Additionally, social restrictions have reduced habitat management performance, farmers institutions and livelihoods, harvesting, and marketing. This has increased pressure on the livelihoods of forest honey bee farmers than before the pandemic. Moreover, it has directly affected their lives and the ability to provide quality forest honey. Therefore, interventions are needed to strengthen marketing and institutional networks to face the changes during and after the COVID-19 pandemic.
\end{abstract}

Keywords: Rural communities; NTFPs; provision services; habitats; institutional

\section{Introduction}

The relationship between forests and humans has existed for a long time, especially as a source of raw materials for basic needs (Rasmussen et al. 2017; Kibria et al. 2018; Ali and Rahut, 2018; Kumar et al. 2019; Hussain et al. 2019; Damania et al. 2020). For instance, some forests provide food, woodwork, animal feed, water, energy, medicinal plants, and socio-cultural and religious attributes (Lee et al. 2015; Dash et al. 2016; Nepal et al. 2017; Ali and Rahut, 2018; Chow, 2018; Koffi et al. 2018; Barua et al. 2020; Umaya et al. 2020; Njurumana et al. 2020). Also, raw materials from the forests are a major source of community livelihood (Oli et al. 2016; Hussain et al. 2019; Ali et al. 2020) through the exchange rate (Ali and Rahut, 2018; Njurumana et al. 2020). However, this relationship has been affected by the COVID-19 pandemic through increased hardship, encroachment, illegal logging, and forest destruction (Golar et al. 2020; Mohan et al. 2021). Furthermore, social restrictions have changed access to forest resource use, such as honey used for health purposes (Hossain et al. 2020; Al-Naggar et al. 2020). These restrictions affect honey bee farmers, the management activities, and the availability of their products in the market.

Information regarding the management and marketing dynamics and their implications for the forest honey bee farmers livelihoods during the pandemic remains a mystery. Previous studies showed an increase in deforestation during the pandemic period (Golar et al. 2020; Brancalion et al. 2020; Mohan et al. 2021), including changes in natural recreational activities 
(Derks et al. 2020). Furthermore, forestry law enforcement was simplified (Guardian, 2020) due to population pressure and changes in access to forest livelihoods (Workie et al. 2020; Sharma and Mahendru, 2020; Paudel, 2020; Anon, 2020; Corlett et al. 2020, Taylor, 2020). Therefore, this study complements the literature on the short-term effects of the COVID-19 pandemic on the forestry sector. Specifically, it examines the changes in habitat management, harvesting, marketing, farmer institutions, and the livelihoods of forest honey farmers around the Mutis mountain forest, Timor island.

\section{Materials and Methods}

\subsection{Conceptual Framework}

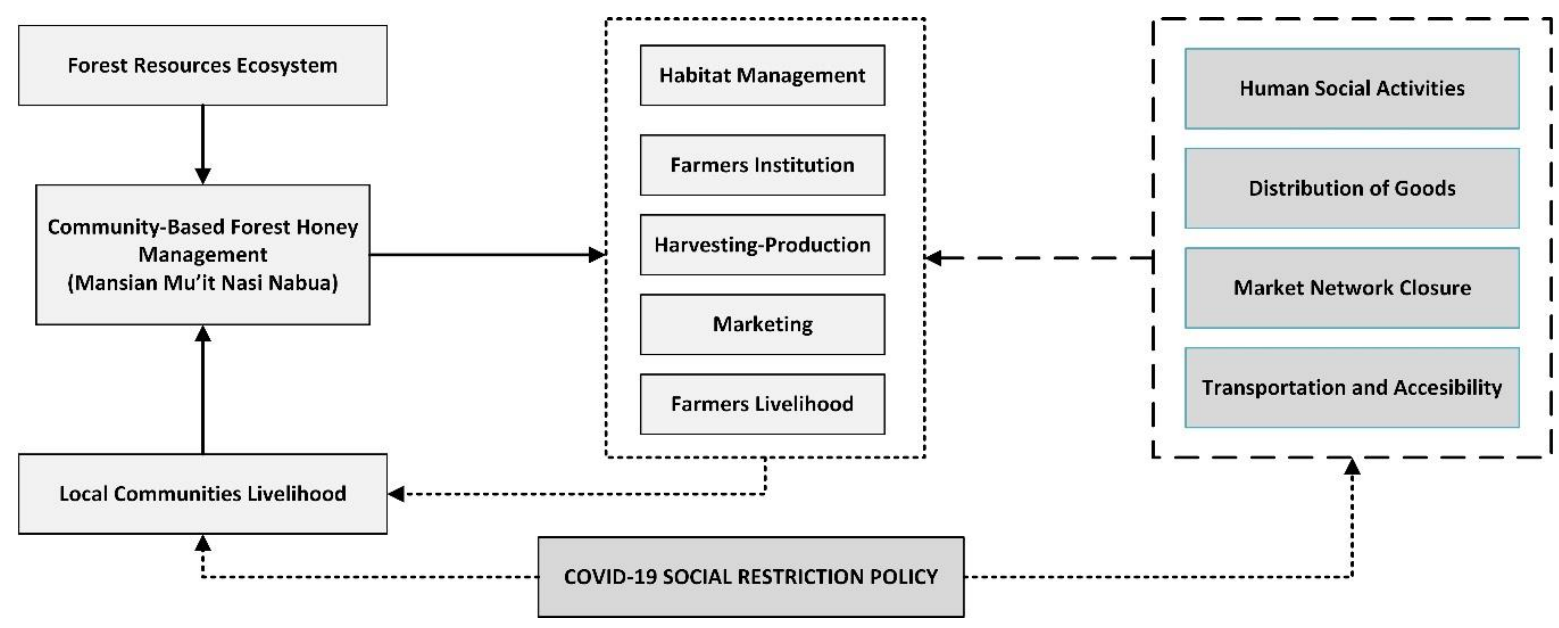

Figure 1. Flow chart of potential impact of COVID-19 social restriction policy on the livelihood of forest honey farmers in Mutis (Source: Developed from Wannaprasert and Choenkwan (2021))

The COVID-19 pandemic has multiple implications for the global community, causing fear and human death in various countries (Goniewicz et al. 2020; Pfefferbaum and North, 2020; Saadat et al. 2020; Zhou et al. 2020). It has affected various sectors of life (Rowan and Galanakis, 2020), especially the source of livelihood, food value chain, income, basic needs fulfillment, and public health (Shammi et al. 2020; Tamru et al. 2020; Brickell et al. 2020; Sharma \& Mahendru, 2020; Oncini et al. 2020; Paudel, 2020; Anon, 2020; Corlett et al. 2020; Taylor, 2020; Berretta et al. 2020; Rowan and Laffey, 2020; Wannaprasert and Choenkwan, 2021). The conceptual framework (Figure 1) explores the human-forest relationship through habitat management, farmer institutions, harvesting, marketing, and livelihoods during the COVID-19 pandemic (Chao, 2012; Gentle et al. 2020; Hossain et al. 2020; Al-Naggar et al. 2020; BBS, 2020; Mohan et al. 2021; Lima et al. 2021; Laudari et al. 2021; Davila et al. 2021). This relationship has changed due to social restriction policies during the pandemic, especially on transportation access, goods distribution, marketing networks, and community social activities.

\subsection{Study Site}

This study was conducted from August to September 2020 in five sample villages of Fatumnasi Subdistrict, South Central Timor Regency, East Nusa Tenggara (ENT), Indonesia (Table 1; Figure 2). The villages were categorized as very underdeveloped, located at 1,276-1,751 m above sea level. They experience 115 rainy days and 2,384 $\mathrm{mm}$ of rainfall annually (BPS, 2019). Furthermore, they are part of 2,308 villages surrounding forest areas in ENT (Njurumana et al. 2020), 292 in ENT, and 6,381 in Indonesia around conservation areas (Wiratno, 2018). 
Table 1. Population demographics of Fatumnasi Subdistrict, ENT.

\begin{tabular}{lccccccc}
\hline Village & \multicolumn{3}{c}{ Population } & \multicolumn{2}{c}{ Households } & \multicolumn{2}{c}{ Village Area } \\
\cline { 2 - 8 } & Male & Female & Total & Units & $\begin{array}{c}\text { Family } \\
\text { Members }\end{array}$ & $\begin{array}{c}\text { Square } \\
\left(\mathrm{km}^{2}\right)\end{array}$ & $\begin{array}{c}\text { Population } \\
\text { Density }\end{array}$ \\
\hline Fatumnasi & 787 & 821 & 1608 & 433 & 4 & 34,97 & 46 \\
Nenas & 603 & 640 & 1243 & 271 & 4 & 58,57 & 21 \\
Kuanoel & 621 & 623 & 1244 & 322 & 4 & 38,24 & 33 \\
Nuapin & 1135 & 1140 & 2275 & 462 & 5 & 55,91 & 41 \\
Mutis & 279 & 297 & 576 & 116 & 9 & 10,96 & 53 \\
\hline
\end{tabular}

Source: Data processed from BPS (2020)

The population in Fatumnasi District is $50.60 \%$ dominated by female, with four people as the average number of family members. Mutis, Fatumnasi, and Nuapin villages have population densities above the Fatumnasi subdistrict average of 39 people $/ \mathrm{km}^{2}$ (BPS, 2020). However, their population densities are lower than the South-Central Timor district average of 115 people $/ \mathrm{km}^{2}$ (BPS, 2021). Supporting facilities such as electricity networks from PLN (state electricity company) are only $34.1 \%$ of family units. This has resulted in weak telecommunication access, causing a high dependence on firewood.

Mutis mountain ecosystem comprises 19,586 hectares of protected forest and 12,316 hectares of nature reserves. These reserves have socio-cultural, economic, and environmental values for local communities (Dako et al. 2018; Dako et al. 2019; Pujiono et al. 2019; Budiman et al. 2020). Moreover, its socio-cultural values symbolize sociological existence for local communities, providing economic benefits as a source of livelihood. Economic activities include raising livestock and utilizing non-timber forest products, such as honey, mushrooms, firewood, medicinal and ornamental plants, natural tourism, and environmental services. The ecological value represents the rich biodiversity of flora and fauna and is one of the mountain tropical forest landscapes (Pujiono et al. 2019). Furthermore, it is a water catchment area for the Benain, Noelmina, and Noelfail watersheds. The three watersheds cross five of the six districts on the island of Timor, including the Democratic Republic of Timor Leste (Dako et al. 2018; Riwu Kaho et al. 2019).

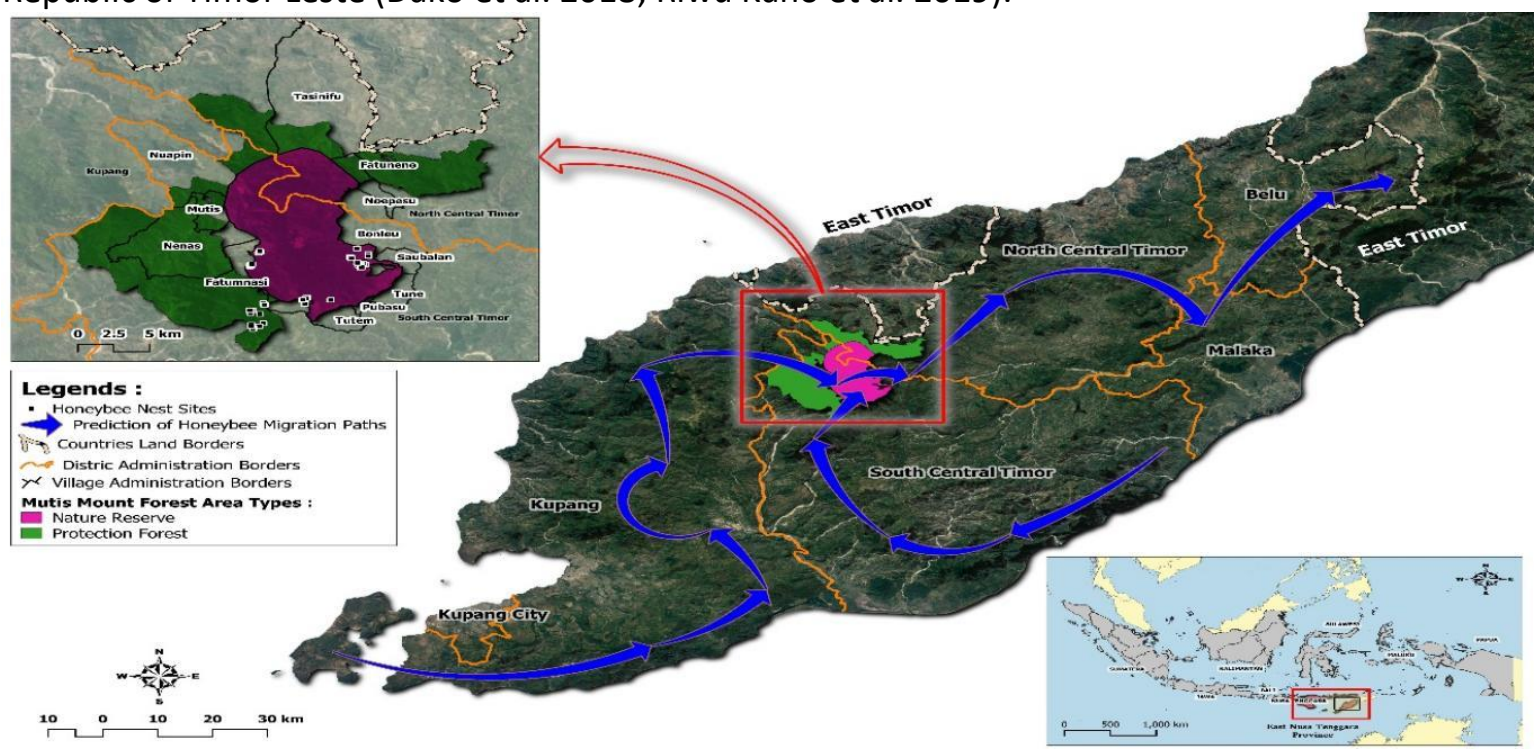

Figure 2. Map of the Mutis forest area on the Timor island (Source: Riwu Kaho and Nomeni, 2019)

\subsection{Data Collection Procedures}

This study was conducted using secondary data from government agencies and primary data from relevant respondents. Primary data were obtained using questionnaires and in-depth interviews with $35(23.5 \%)$ of 149 households of forest honey bee farmer members of the Mutis Community Network (Jaringan Masyarakat Mutis (JMM)). This is an organization around the Mutis forest area that manages, harvests, and markets forest honey. Respondents for primary data comprised forest honey farmers, JMM administrators, traditional leaders, and village officials.

The data and information were collected on habitat management, harvesting, marketing, 
farmer institutions, and livelihoods. Also, interviews with JMM administrators covered the institutional dynamics of farmer groups amid the COVID-19 pandemic, including interventions for forest honey bee habitat management. The interview with traditional leaders examined the challenges of traditional changing of harvesting honey, including management of customary areas (Suf) for production. Each respondent was given several questions about the changes in forest honey management and the implications for household resilience. Measurement indicators on a scale of 1-5 was determined and continued with an in-depth interview to determine the causing factors.

\subsection{Research Variables and Data Analysis}

This study used five variables and 30 study indicators in data collection. These variables include habitat management, harvesting, marketing, farmer institutions, and their livelihoods. They are considered influential factors for honey management dynamics in the Mutis forest area.

The primary data and information from in-depth interviews were analyzed descriptively and quantitatively. Analysis involved data tabulation, as well as weighing and scoring the change categories on the five variables and 30 indicators based on Becker et al. (2017) and Miller et al. (2017) with adjustments. Determining variable and indicator weights refers to the accumulated change values on a scale of 1-5. The change for each indicator was classified into five scales as very low (1), low (2), medium (3), high (4), and very high (5). Also, the result value was determined by the accumulated score of the indicator on each variable.

$$
K=\sum_{i e=1}^{n}\left(w_{i e} \times x_{i e}\right) \quad \begin{aligned}
& \mathrm{K}=\text { Indicator change category } \\
& \text { Wie }=\mathrm{i} \text {-th indicator's weight } \\
& \text { Xie }=\mathrm{i} \text {-th indicator's score }
\end{aligned}
$$

\section{Results and Discussion}

\subsection{Demographic Profile of Informants}

Most forest honey bee farmers are male because harvesting is physical work lasting several days or weeks based on the traditional management (Suf). The farmers survey potential bees during the season, plan the time for traditional ceremonies, and harvest honey in the Suf area. In contrast, female help in planning and harvesting by providing logistical needs and processing honey and wax through draining.

As Figure 3 shows, most farmers have a secondary school education, though they come from disadvantaged villages around the Mutis forest (BPS, 2020). The limited management capacity requires innovation and technology transfer support, especially in harvesting and processing forest honey to meet quality standards. This is because honey farming has good prospects, and most farmers are of productive age with sustainable management potential. Furthermore, $85.7 \%$ of farmers have long experience in farming honey forests. They mostly belong to the Timorese ethnic group, born and grew up in rural areas around the Mutis forest. Moreover, they have a high social kinship and relatively homogeneous customs, including recognizing the surrounding area and natural potential. They also manage beehive trees and facilitate the development of forest honey bee farming.

\subsection{Dynamics of Forest Honey Bee Management}

Forest honey management needs regulation to ensure quality, economic value, and benefits for different human needs (Grabowski \& Klein, 2017; Nguyen et al., 2018). This management is expected to meet public demand for high-quality honey products on a national and international scale. Saudi Arabia is one of the importing countries, reaching $74 \%$ of the national need (Alnafissa \& Alderiny, 2019). However, this massive demand is not accompanied by standard management because honey is the 6th food group prone to contamination (Aljohar et al. 2018; Soares et al. 2019; Moškrič et al. 2020; El-Nahhal, 2020). The management is expected to sustain the honey bee habitat, including ensuring an environmentally friendly and hygienic production system (Durant, 2019; Kovács-Hostyánszki et al., 2019). Subsequently, preserving bee habitat and honey production significantly determines the sustainability of the livelihoods of communities around the forest (Wahlen, 2017; Matias et al., 2018). 
Forest honey has been managed conventionally using customary rules as a source of law to regulate the resources. Government regulations strengthened the customary rules by integrating forest honey in 591 non-timber forest product commodities (NTFPs) in Indonesia (MoF, 2007). Its implementation refers to Local Government Regulation (LGR, 2017), regarding the management of NTFPs in ENT and its derivative regulations. One of these regulations is Governor Regulation concerning the Mutis honey center (LGR, 2020).

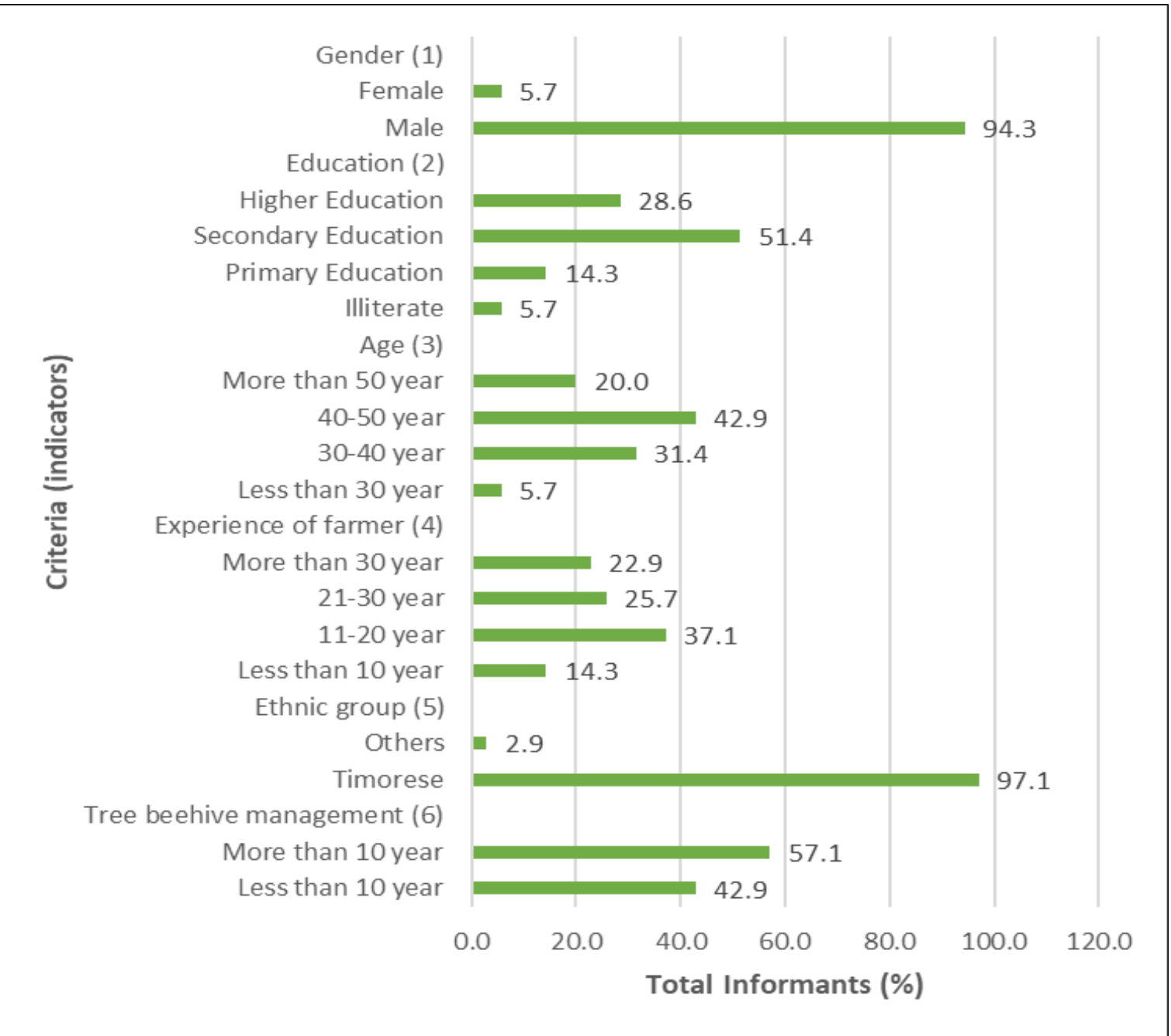

Figure 3. Demographic profile of informants in Mutis Sub District (Source: Primary Data, 2020)
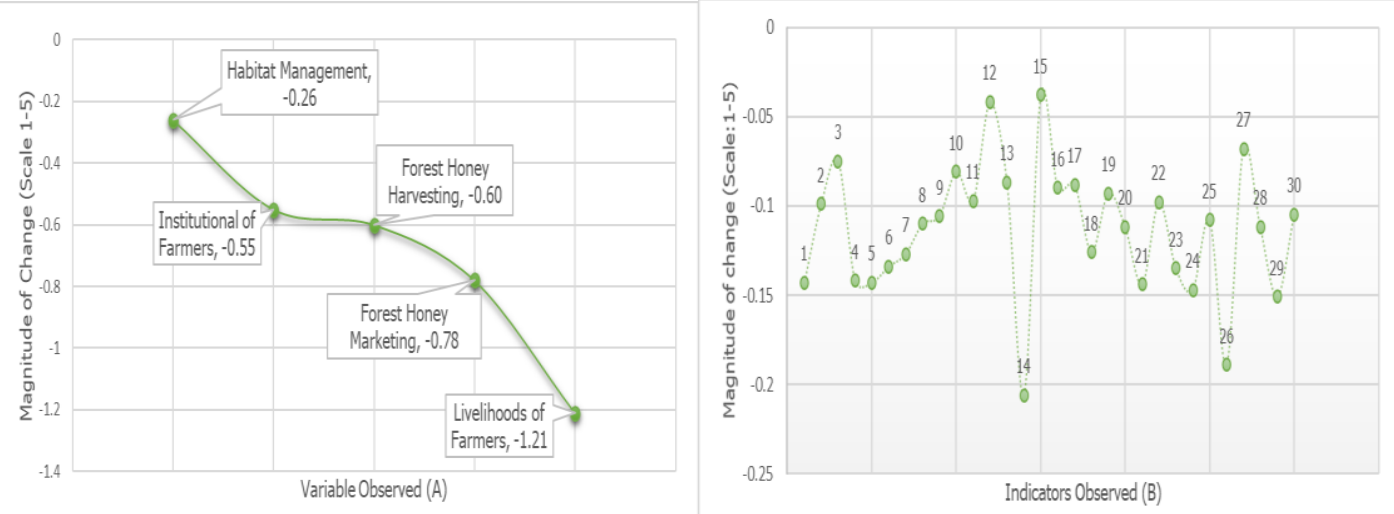

Figure 4. Change value of the variable (A) and indicator (B) observed (Source: Primary Data, 2020) 
Regulating forest honey management as a leading NTFP aims for habitat conservation, continuous production, marketing strategies, and increasing income to farmers and state. However, the COVID-19 pandemic has created new challenges in forest honey management and utilization. This is seen from the declined performance through five variables and 30 indicators (Figure 4), increasing farmers' livelihoods challenges. Varying changes in each variable, including livelihoods, are caused by changes in each measuring indicator. These include economic difficulty, farmers' expenditures, changes in income, access to production facilities, government assistance, and farming development. Furthermore, the decrease in each variable and indicator implies declined performance of forest honey farmers during the COVID-19 social restrictions.

Forest honey farmers in Mutis are part of 8,643,228 families in Indonesia (BPS, 2018), 140 million people of Southeast Asia (Moeliono, 2017), and between 1.6 and 1.85 billion people worldwide (Chao, 2012; FAO, 2015; Miyamoto, 2020; Mohan et al. 2021). These farmers depend on forests for their livelihoods, jobs, and income. Optimizing forest benefits is influenced by the institutional role of farmer groups. This is because they have social capital, understand community conditions, and assist their members in dealing with the COVID-19 pandemic (Gentle et al. 2020). The forest honey harvesting variable is affected mainly by access restrictions with implications for its harvesting and utilization (Hossain et al. 2020; Al-Naggar et al. 2020; Lima et al. 2021). This includes marketing constraints due to limited product distribution during the pandemic (BBS, 2020; Lima et al., 2021). Consequently, limited marketing affects livelihood sources, increasing economic hardship and poverty. Moreover, it causes the suspension of forestry activities, increasing illegal logging, and decreasing forestry's economic contribution (Laudari et al., 2021). Studies in the Solomon Islands, Vanuatu, PNG, and Timor Leste have shown an increase in poverty and a decrease in per-capita income and household consumption during the COVID-19 pandemic (Davila et al. 2021).

\subsubsection{Habitat Management}

The forest honey bee habitats, such as water, food, and vegetation, are factors determining the colony's sustainability. However, the improvement of habitat management has encountered problems because most are located in protected forest areas and nature reserves. These areas experience access restrictions due to the COVID-19 pandemic. On the contrary, the community has a traditional Suf-based management area within the state forest. It is estimated to reach 11,400 ha, managed by at least 226 family units in the Mutis forest area (Riwu Kaho \& Nomeni, 2019). Moreover, Suf land has socio-cultural value because it provides economic and ecological benefits and is the cultural landscape of local communities (Dharmiasih, 2020). Community synergy with forest area stakeholders is needed to improve habitat quality for the strategic value of forest honey for farmers' livelihood. Also, this synergy should increase traditional ceremonial sites in the Suf area to protect nest and forage trees in state forests.

Ampupu (Eucalyptus urophylla) is the dominant vegetation of the Mutis Forest and the primary breeding ground and food source for honey bees. The dominance level indicated that the important value index (IVI) at the tree, poles and sapling levels reached $134.0 \%, 66.1 \%$, and $69.6 \%$, respectively. In contrast, the understorey was dominated by Cromolaena odorata with an IVI value of $119.7 \%$ (BBKSDANTT, 2018). Furthermore, the domination of ampupu has implications for the ecological services of the Mutis forest in honey production. This is because $97 \%$ of the honeycomb is found in the trees growing on a slight to very steep topography (Riwu Kaho \& Nomeni, 2019). The large growing space supports the availability of nectar and pollen, including the adaptation for forest honey bees to utilize dominant tree species, such as ampupu (Nagir et al., 2016). On the contrary, natural regeneration is decelerating and requires intervention to accelerate the process and support its ecological role in the future. However, the farmers' participation in managing and protecting natural plant regeneration due to illegal grazing and forest fires has been hampered by access restrictions during the COVID-19 pandemic.

One threat to the forest honey bee habitat is $87.5 \%$ and $96.9 \%$ the need for firewood and carpentry activities in the Mutis forest area respectively (Dako et al. 2018). This pressure has contributed to the decline in densely vegetated forests in the past 30 years (Pujiono et al. 2019), affecting the habitat's carrying capacity. Therefore, control is needed to maintain the forest honey 
bee habitat and the carrying capacity of its ecosystem (Woyke et al., 2012). The pressures on land use and cover changes are consistent with farmers information regarding the decreasing population of Apis dorsata's hive and forage trees in the last five years. This information supports the analysis results that a decrease in habitat management reduces other variables. The pressure has been increased by the limited access to control by forestry agencies and honey farmer institutions during the pandemic. Consequently, it has implications for increasing honey bee habitat destruction.

Farmers realize that increasing the quality and quantity of forest honey bee habitat determines the production and utilization sustainability. Furthermore, planting is carried out to build food security and economic resilience amidst the impact of the pandemic. Therefore, they cultivate plants that produce nectar in gardens and yards, including Citrus reticulata, Persea americana, and Coffea arabica. Moreover, they maintain trees that grow naturally around the garden, such as Myristica sp., Ficus sp., Bombax malabarica, Acacia leucophloea, Scheilera olease, Areca catechu, Cocos nucifera, Albizia Chinensis, Gyrocarpus americanus, Wenlandia buberkilli var. timorensis, Todalia asiabeca and Albizzia Saponaria. The farmers participation in tree conservation and the enrichment of species through cultivation improves human and environmental ecosystem services (Njurumana, 2016; Njurumana, 2019; Durant, 2019; Bänsch et al. 2020; Wakhidah et al. 2020).

\subsubsection{Forest Honey Bee Farmer Institutions}

The resilience of farmers institutions during the pandemic impacted forest honey management because the JMM group members were less affected by social distancing. This is because the institutional coordination has not changed significantly than before the pandemic. Additionally, several indicators that contributed to change limit farmer group meetings, resulting in management coordination without members. The village distribution of JMM farmer members experiences inaccessibility through expensive long-distance transportation costs and restricted human movement. This makes the work agenda of farmer groups experience obstacles, affecting performance. Furthermore, all farmer group members' coordination and regular meetings were stopped due to social restrictions. As a result, the implementation of the work program experienced changes in priorities and targets. The collective agreement in organizing farmers has also adjusted to the pandemic situation. Subsequently, several new agreements have become a reference in management and marketing. The agreements include eliminating regular meetings of farmer group members and authorizing only one core management to coordinate the honey management and marketing.

External factors and the awareness of COVID-19 spread have influenced the access and efficiency of forest honey marketing. The interview results showed a sales decline from $10-60 \%$, with an average change of 0.133 in sales value (Figure 4 (B) indicator 6), especially honey farmers outside the JMM organization. The honey processing by JMM members applied quality standards, while other farmers use conventional methods. As a result, this has destabilized honey prices outside the organization due to the urgent need for money and the low bargaining position of farmers. As a countermeasure, this requires assistance to improve honey processing according to established standards. Several agreements regarding forest honey management are proposed by farmers, especially the security of nest trees due to increased bee colonies. As a result, the security of the forest honey bee colony is well maintained due to clear boundaries of customary management areas. This creates a small possibility for taking honey except outside the Suf area (local term: wild honey), accessible to the general public. Also, pressure on forest destruction, such as land fires, has decreased during the pandemic.

\subsubsection{Harvesting}

Harvesting is a routine annual agenda carried out by the community between January and March, as well as from May to July. This adjusts the flowering season for several types of honey bee forage plants. Forest honey utilization manifests the triangle philosophy of community life, known as mansian, mu'it,nasi nabua'. This means that humans, forests, and livestock (all life in the forest) are an inseparable unit that supports each other. The relationship works in synergy to encourage the use of Mutis forest ecosystem's natural resources to maintain function and balance. When one of the three components is neglected, the community considers it management malpractice. 
The philosophy's manifestation encourages forest honey utilization according to community traditions. This usually begins and ends with a traditional ceremony attended by between 50 and 150 people in the Suf area. Each clan owns and understands the boundaries of the manage Suf area. They use natural boundary markers such as rivers, ridges, and natural stones. Furthermore, traditional ceremonies involve the community, religious and traditional leaders, and the general public to ask permission for forest honey utilization. After harvesting, they perform a ceremony to recall the flying honey bees to occupy the colony.

Traditional ceremonies for harvesting forest honey have been simplified by adjusting to social restrictions during the pandemic. These have reduced the number of people involved in these ceremonies and harvesting. Moreover, the restriction reduces the socio-cultural legitimacy of customs and culture in the harvesting process. The community believes that cultural practices in the use of forest honey should not be simplified because it causes losses during harvesting. This farmers' confidence supports the 2020 data on forest honey harvesting from 149 households in the JMM group. It showed a decrease of 1700 liters (54.7\%) from the average harvest yield of 3,106 liters annually between 2009 and 2019.

Farmers believe that the honey production decline is caused by simplifying traditional honey harvesting ceremonies during the pandemic. This is a reduction of social responsibility (customary attributes) towards nature, with implications for the ecological services obtained through the volume of forest honey production. Furthermore, this traditional ceremony signifies the exchange of equal resources with the environment as a honey producer. However, some farmers do not conduct the ceremonies because the harvest potential is not equivalent to the material sacrificed in the ceremony. Instead, they only involve nuclear family members in honey harvesting as a solution. The honey produced from managed bee trees ranges from 5 to 15 trees per family, yielding between 50 and 250 liters. However, this is lower than the production in the Sisimeni Sanam forest area in 2019, ranging between 500 and 1,215 liters (Mooy, 2020). The presumption of this difference is due to the influence of the COVID-19 pandemic and the comparison of the number of honey farmers in the Mutis forest.

The availability of professional climbers also determines the quality and quantity of honey yields, especially in reaching the beehives on tall trees with large diameters. Regeneration of the climbing profession has not been well organized because it is limited in number and affects the harvest timeliness. Furthermore, most climbers do not have Suf because they seek employment in urban areas. The COVID-19 pandemic movement restrictions have made most climbers working as laborers in urban areas not return to the village for honey harvesting. Travel regulations require a COVID-19-free letter from a health agency, with a very short validity period and high cost. However, forest honey should be harvested on time to maintain its quality and quantity. The limited availability of climbers creates competition for users. As a result, this increases the service bargaining between forest honey bee tree owners and climbers. Additionally, the scarcity increases the commitment of climbing services from $30 \%$ to $50 \%$ of the total yield. This is almost equivalent to the commitment of climbers in the Sisimeni Sanam area, reaching 50\% of the harvest (Mooy, 2020). Economically, this business is profitable because the climbers' share is almost equivalent to the forest honey bee tree owners.

\subsubsection{Marketing}

The forest honey marketing was subject to social and regulatory restrictions during the COVID19 pandemic due to changes in access within and outside the district. Subsequently, restrictions of social and transportation access affect human movement with direct implications for forest honey demand. The largest decrease occurred in the community that conducted individual marketing ranging between $10-70 \%$ from the previous condition. This decline is due to the difficulty of access for buyers outside the village to take directly harvested forest honey from the farmer. It was caused by limited transportation facilities, including strict travel requirements and expensive costs. However, the situation is different in the organized honey marketing through the JMM farmer group. The selling price is more stable because it has a definite sales agent, and the organization bears operational costs. Also, the honey marketed meets product processing standards, hygienic packaging. The distribution processes apply the COVID-19 standard protocol, building consumer 
confidence to buy.

Honey marketing is a challenge for those working individually, and a drop of $87 \%$ has also declined the bargaining power of farmers. This has decreased the selling price by between 30 and $40 \%$ from the previous condition. There has been an urgent demand for necessities and medicines during the pandemic and difficulty in obtaining cash. This has promoted the system of exchange or bartering goods for goods among the community. Farmers admitted that the system relies heavily on bargaining power with the kiosk or shop business owner. Additionally, pricing is not commensurate with the selling value of honey under normal circumstances before the pandemic. Another influencing factor is the less optimal internal coordination between forest honey management and farmers during the pandemic period. Also, the movement of special and mass tourists from outside the village significantly declined. This situation limits forest honey marketing, especially those expecting foreign tourists.

\subsubsection{Livelihoods of Forest Honey Bee Farmers}

Most farmers in Mutis Forest depend on agriculture, forestry, and animal husbandry for their livelihoods. The income per capita is around Rp. 201,894-368,929 per month (Dako et al. 2018), less than the district average of Rp. 690,269 (BPS, 2018) and Rp. 711,629 (BPS, 2020). Furthermore, they cultivate with productivity of five tonnes of rice and three tonnes of maize per hectare. This includes livestock cultivation, such as horses, cows, goats, pigs, and native chickens (BPS, 2020).

The livelihoods of forest honey farmers experienced changes in several observed indicators during the pandemic. The majority experienced a decline in income by $10-60 \%$ from pre-pandemic conditions due to the reduced volume of honey harvested and limited marketing accessibility. Moreover, online marketing has not been developed due to low technology mastery complicated by limited job alternatives, such as services, implying decreased access to cash.

Social restrictions and accessibility have decreased the livelihood sources of forest honey farmers by $20-80 \%$. Therefore, farming development aims to improve food security and optimize the use of food sources on managed farms. Also, additional efforts were made through increased diversification of crops and horticulture to build food security and reduce household expenditure. These limitations have increased the economic difficulties of forest honey farmer households from $10-60 \%$ from the previous condition.

The economic difficulties faced by farmers during the COVID-19 pandemic have encouraged the increased development of various agricultural commodities. This has been accomplished by intensifying agricultural land use by $10-40 \%$. The cultivated commodities are plants that support food security and household income. They include shallots (Allium cepa), garlic (Allium sativum), potatoes (Solanum tuberosum), cayenne pepper (Capsicum annum), corn (Zea mays spp), peanuts (Arachis hypogaea), cassava (Manihot esculenta), and sweet potato (Ipomoea batatas). Furthermore, farmers cultivated biopharmaceutical plants, traditionally used to improve health and immunity during the pandemic. Examples include ginger (Zingiber officinale), galangal (Alpinia galanga), cutcherry (Kaempferia galanga), turmeric (Curcuma longa), and Curcuma (Curcuma zanthorrhiza).

The limited livelihoods have reduced the income of forest honey producers by 10 to $70 \%$ compared to the previous state. Furthermore, access to facilities and infrastructure for honey production is limited, especially tools for washing, storing, packaging, and producing. This change was influenced by restrictions on distribution routes and transportation accessibility during the pandemic.

The decrease in production has reduced forest honey consumption by $10-50 \%$ for farmer families. The average consumption reached $0.91 \mathrm{~g}$ per capita per day, lower than the average for the ten highest honey-consuming countries of 3.01-9.62 per capita per day (FAO, 2019). Additionally, farmers prioritize marketing to obtain cash to buy necessities and overcome the 10-60\% decline in food security from the previous condition. They also optimize the use of food resources on garden land to meet family needs. This includes receiving government social assistance for food security during the COVID-19 pandemic. 


\subsection{Discussion}

Sustainable forest management is an important activity for honeybee habitat management that increases productivity as a source of livelihood for 80-95 million people in Indonesia (Chao, 2012; Mohan et al., 2021). Farmers that hunt forest honey are generally in groups and organized in institutions with strong social ties to jointly mitigate the impact of the COVID-19 pandemic (Gentle et al. 2020). However, harvesting and marketing of forest honey and farmers livelihoods are affected by social restrictions. Moreover, they experience difficulties harvesting and utilizing forest honey due to limited marketing distribution channels (Hossain et al. 2020; BBS, 2020; Al-Naggar et al. 2020; Lima et al., 2021). This builds livelihood pressures that drive economic hardship and increasing poverty (Laudari et al. 2021; Davila et al. 2021).

Social restrictions during the COVID-19 pandemic have decreased community activities, natural tourism visits, and special interest tours around the Mutis forest. This decline triggers economic networks and community livelihoods changes, including farmers access to harvesting forest honey. As an economic activity, harvesting integrates socio-cultural aspects through the usual ceremonies as the main input. Additionally, customary ceremonies are a collective agenda carried out regularly by forest honey farmers. They strengthen solidarity with the universe and fellow communities with genealogical relations.

The social restrictions at the peak of the honey harvesting tradition influence community participation. The people believe that the customary rituals significantly affect the quantity and quality of the harvest. Furthermore, socio-cultural legitimacy through customary ceremonies motivates the community and harvesting personnel in carrying out their duties. This means that harvesting is an economic activity and a socio-cultural collective action to unite society supporting each other. Therefore, it is momentum for solidarity with the community, traditional and religious leaders, the indigenous peoples. Each clan has a role in the ceremonies, and those involved in the traditional aspect seek permission for forest honey utilization.

The challenge in honey harvesting is bridging the rationalization and simplification of smallscale traditional rituals during a pandemic. Furthermore, the simplification decreases the unity and intrinsic values and tradition inheritance to the younger generation. This implies fading solidarity among stakeholders in forest honey management. Moreover, social restrictions limit the transfer of meaning and cultural values. It also limits the participation of young people to experience the internalization of socio-cultural values in utilizing forest honey. This may lead to a chain break of inheriting these values in forest resource management. Consequently, it reduces forest honey management meaning to mere economic activity. Therefore, the synergy of socio-cultural, economic, and ecological aspects is weakened, reducing local values in managing natural resources, such as forest honey.

The limitation of bee tree climbers is also a challenge interpreted as a professional cultural monopoly to benefit certain parties. Additionally, the tendency for young climbers to seek a source of livelihood in urban areas negatively impacts the climbing profession. As a result, farmers are in constant need of skilled climbers to help harvest forest honey. Therefore, customary and community leaders should evaluate these policies and allow other parties to pursue the profession and optimize the harvesting of forest honey during and after the COVID-19 pandemic.

The community's socio-cultural use of forest areas is an ornament that enriches the value of the forest benefits. Subsequently, the resources become an economic commodity interspersed with socio-cultural and religious-human interests. When these three aspects are closely integrated, they become a leveraging factor for increasing community participation in forest conservation. Therefore, forests, with all their resources, are the main input for functioning socio-cultural, religious, and economic instruments. Although the local community balances these tools, they should be improved to cover forest conservation efforts and community livelihoods.

Management and protection of forest honeybee habitats should not decrease during the COVID-19 pandemic because it affects production and farmers livelihoods. There is a strong mutual beneficial co-existence relationship between honey bees and flowering plants in the forest and yard. This is because bees obtain nectar and pollen from plants, with implications for their populations and forest honey production for farmers. Therefore, honey production during and after the 
pandemic is a function of the habitat's carrying capacity. The sustainability of forest honey production is determined by the management and improvement of the quality of habitat by farmers. Habitat management interventions by farmers during the COVID-19 pandemic are carried out by increasing dryland farming-based livelihood sources with forest honeybee habitat enrichment. This is through cultivating plant species to improve livelihoods and health sources (biopharmaceuticals) during the pandemic. Additionally, the plants serve as forest honeybee feed trees in the buffer zone of the Mutis nature reserve and protected forest. Habitat enrichment interventions on agricultural cultivated land bring the sources of forage and bee trees closer to farmers settlements, enhancing monitoring, management, and harvesting.

\section{Conclusion}

This study complements the literature on the short-term impact of the COVID-19 pandemic on forestry. It examines the changes in habitat management, harvesting, marketing, farmer institutions, and the livelihoods of forest honey farmers around the Mutis mountain forest. The community considers forest honey a strategically valuable commodity socio-culturally, economically, and ecologically, and a source of livelihood. The strategic value of forest honey encourages collective management, strengthening kinship, and social solidarity. Furthermore, it strengthens human and forest relations as a manifestation of the triangle of life in the Mutis community.

The COVID-19 pandemic and social restriction policies have reduced the institutional performance of forest honey farmer groups in habitat management, harvesting, marketing, and livelihoods. As a socio-cultural tradition, forest honey harvesting has been simplified by restricting community participation, decreasing honey production. Moreover, social restrictions have caused a decline in demand and marketing of honey products, decreasing income sources for forest honey farmers livelihoods. Therefore, the farmers initiated the cultivation of crops and biopharmaceuticals to support food security and income sources. Furthermore, there is a need for internal consolidation by strengthening the institutional performance of these farmers to mitigate the impact of social restrictions during the pandemic.

\section{Recommendations for Livelihoods-Sustainability}

The farmers capacity in habitat management should be increased to support the sustainability of their livelihood sources. Also, it is necessary to strengthen harvesting strategies and farmer institutions and expand marketing networks. Habitat management should be strengthened through intervention by forest area stakeholders to improve the socio-ecological functions of traditionally managed areas. This could be accomplished through the participatory cultivation of forest plants. Since most honeybee habitats are in forest areas, their utilization should be following regulations through social forestry schemes. This ensures the sustainability of the ecological functions of the forest and increases community welfare. Furthermore, habitats should be developed on customary and private lands by maintaining and protecting various feed and nest trees growing naturally from the risk of fire and damage by loose livestock.

Improving the honey bee habitat should be followed by increasing the farmers capacity to harvest forest honey to maintain its quality and quantity. This could be carried out through strengthening the technical capacity of climbers to professionally pay attention to work safety aspects. Other improvements include setting up service standards for climbers, and transforming cultural barriers to regenerate climbers in quality and quantity. Additionally, the local government should facilitate village youth to participate in harvesting training. They should also be involved in post-harvest honey processing, including using equipment to diversify products according to market needs. The resulting honey product needs to be packaged in various shapes and sizes to have a competitive and comparative value. Furthermore, forest honey farmer institutions need to innovate in strengthening wider marketing networks. This includes the use of online marketing to facilitate and ensure market certainty for their products. The role of this institution is important in improving the management capacity of business-oriented organizations. Consequently, it strengthens the farmers entrepreneurial capacity in marketing forest honey, expands organizational networks, and increases farmer group members. 


\section{Areas for Further Research}

This study obtained a strong relationship between the influence of the COVID-19 pandemic on the livelihoods of honey farmers as a forest-dependent community. However, further research is required to provide information on different types of forests and commodities. In this context, a study is proposed on farmers resilience, including restoring forest and human relations after the pandemic. The first study should examine the locality mapping of traditional community management outside and inside the forest area and synergize the management policy. The second study needs to examine the dynamics of forest honeybee management and habitat change. This is especially the management and enrichment of honeybee tree species and forest honeybee feed trees in increasing their carrying capacity for honey production. The study should explore the dynamics of forest honey production and the economic value of several NTFP commodities for community livelihoods. The fourth study should explain the challenges and opportunities of climber regeneration in the cultural context of the Mutis people.

Author Contributions: Gerson N. Njurumana (main contributor) conducted the conceptualization and research design, construction research variables, and instrument indicators. Also, Gerson N. Njurumana conducted primary and secondary data collection, reviewed international references, data analysis, manuscript development, revision, and final editing. Norman PLB Riwu Kaho provided a map and secondary data, while Elisa Iswandono, Antonius A. Kian and Sherly S. Wilahuky carried out the secondary data collection. Additionally, Budy Z. Mooy, Fatmawati and Yeni F. Nomeni carried out the primary data collection.

Conflicts of Interest: The authors declare that no conflict of interest was disclosed.

Acknowledgments: The authors are grateful to Amos Oematan, Oktovianus Anin, and Novris Tefa for their assistance in the fieldwork. Also, they are grateful to the farmers for sharing valuable information during the data collection and acknowledge anonymous reviewers for their insightful comments and constructive contribution that greatly helped improve the manuscript.

\section{References}

Al Naggar, Y., Giesy, J.P., Abdel-Daim, M.M., Ansari, M.J., Al-Kahtani, S.N. \& Yahya, G. (2020). Fighting against the second wave of COVID-19: Can honeybee products help protect against the pandemic? Saudi Journal of Biological Sciences, 28(3), 1519-1527. https://doi.org/10.1016/j.sjbs.2020.12.031

Ali, A., \& Rahut. D.B. (2018). Forest-based livelihoods, income, and poverty: Empirical evidence from the Himalayan region of rural Pakistan. Journal of Rural Studies , 47, 44-54. https://doi.org/10.1016/j.jrurstud.2017.10.001

Ali, N., Hu, X., \& Hussain, J. (2020). The dependency of rural livelihood on forest resources in Northern Pakistan's Chaprote Valley. Global Ecology and Conservation, 22, e01001. https://doi.org/10.1016/j.gecco.2020.e01001

Aljohar, H. I., Maher, H. M., Albaqami, J., Al-Mehaizie, M., Orfali, R., Orfali, R., \& Alrubia, S. (2018). Physical and chemical screening of honey samples available in the Saudi market: An important aspect in the authentication process and quality assessment. Saudi Pharmaceutical Journal, 26(7), 932-942. https://doi.org/10.1016/j.jsps.2018.04.013

Alnafissa, M., \& Alderiny, M. (2020). Analysis of Saudi demand for imported honey using an Almost Ideal Demand System (AIDS). Journal of the Saudi Society of Agricultural Sciences, 19(4), 293298. https://doi.org/10.1016/j.jssas.2019.05.001

Anon. (2020). Malaysia's Indigenous people flee into forests to escape coronavirus. Retrieved from www.irrawaddy.com/news/asia/malaysias-indigenous-people-flee-forestsscapecoronavirus. html.

Bänsch, S., Tscharntke, T., Ratnieks, F. L., Härtel, S., \& Westphal, C. (2020). Foraging of honey bees in agricultural landscapes with changing patterns of flower resources. Agriculture, Ecosystems \& Environment, 291, 106792. https://doi.org/10.1016/j.agee.2019.106792 
Barua, S. K., Boscolo, M., \& Animon, I. (2020). Valuing forest-based ecosystem services in Bangladesh: Implications for research and policies. Ecosystem Services, 42, 101069. https://doi.org/10.1016/j.ecoser.2020.101069

Becker, W., Saisana, M., Paruolo, P., \& Vandecasteele, I. (2017). Weights and importance in composite indicators: Closing the gap. Ecological indicators, 80, 12-22. http://dx.doi.org/10.1016/j.ecolind.2017.03.056

BBKSDANTT. (2018). Laporan Evaluasi Kesesuaian Fungsi Cagar Alam Hutan Gunung Mutis. Balai Besar Konservasi Sumberdaya Alam Provinsi Nusa Tenggara Timur.

BBS. (2020). Honey business turns bitter amid the Covid-19 situation. Retrieved from http://www.bbs.bt/news/?p=132670

Berretta, A. A., Silveira, M. A. D., Capcha, J. M. C., \& De Jong, D. (2020). Propolis and its potential against SARS-CoV-2 infection mechanisms and COVID-19 disease. Biomedicine \& Pharmacotherapy, 131, 110622. https://doi.org/10.1016/j.biopha.2020.110622

BPS. (2018). Jumlah dan persentase rumah tangga di sekitar kawasan hutan yang melakukan perladangan berpindah. Retrieved from https://www.bps .go.id/ dynamictable/ 2018/03/21/1291/jumlah-dan-persentase-rumah-tangga-di-sekitar-kawasan-hutan-yangmelakukan-perladangan-berpindah-2004-dan-2014. html.

BPS. (2018). Kabupaten Timor Tengah Selatan Dalam Angka. Badan Pusat Statistik Kabupaten Timor Tengah Selatan.

BPS. (2019). Kecamatan Fatumnasi Dalam Angka. Badan Pusat Statistik Kabupaten Timor Tengah Selatan.

BPS. (2020). Kabupaten Timor Tengah Selatan Dalam Angka. Badan Pusat Statistik Kabupaten Timor Tengah Selatan.

Brancalion, P. H., Broadbent, E. N., de-Miguel, S., Cardil, A., Rosa, M. R., Almeida, C. T., ... \& AlmeydaZambrano, A. M. (2020). Emerging threats linking tropical deforestation and the COVID-19 pandemic. Perspectives in ecology and conservation, 18(4), 243-246. https://doi.org/10.1016/j.pecon.2020.09.006

Brickell, K., Picchioni, F., Natarajan, N., Guermond, V., Parsons, L., Zanello, G., \& Bateman, M. (2020). Compounding crises of social reproduction: Microfinance, over-indebtedness and the COVID19 pandemic. World Development, 136,

105087. https://doi.org/10.1016/j.worlddev.2020.105087

Budiman, I., Fujiwara, T., Sato, N., \& Pamungkas, D. (2020). Another Law in Indonesia: Customary Land Tenure System Coexisting with State Order in Mutis Forest. Jurnal Manajemen Hutan Tropika, 26(3), 244-253. https://doi.org/10.7226/jtfm.26.3.244

Chao, S. (2012). Forest Peoples: Numbers across the World. Forest Peoples Programme, United Kingdom. Retrieved from http://www.forestpeoples.org/sites/fpp/files/publication/2012/05/forest-peoples-numbersacross-world-final_0.pdf

Chow, J. (2018). Determinants of household fuelwood collection from mangrove plantations in coastal Bangladesh. Forest Policy and Economics, 96, 83-92. https://doi.org/10.1016/j.forpol.2018.08.007

Corlett, R. T., Primack, R. B., Devictor, V., Maas, B., Goswami, V. R., Bates, A. E., ... \& Roth, R. (2020). Impacts of the coronavirus pandemic on biodiversity conservation. Biological conservation, 246, 108571. https://dx.doi.org/10.1016\%2Fj.biocon.2020.108571

Dako, F.X., Purwanto, R.H., Faida, L.R.W., \& Sumardi. (2018). Firewood and carpentry wood contribution to the communities of Mutis Timau protected forest, Timor Island. Jurnal Manajemen Hutan Tropika, 24(3), 166-174. http://dx.doi.org/10.7226/jtfm.24.3.166

Dako, F.X., Purwanto, R.H., Faida, L.R.W., \& Sumardi. (2019). Tipologi Pola Konsumsi Pangan Untuk Menjaga Ketahanan Pangan Masyarakat Sekitar Kawasan Hutan Lindung Mutis Timau KPH Kabupaten Timor Tengah Selatan. Jurnal Ketahanan Nasional, 25(1), 92-106. https://doi.org/10.22146/jkn.39544.

Damania, R., Joshi, A., \& Russ, J. (2020). India's forests-Stepping stone or millstone for the poor?. World Development, 125, 104451. https://doi.org/10.1016/j.worlddev.2018.11.007 
Dash, M., \& Behera, B. (2016). Determinants of household collection of non-timber forest products (NTFPs) and alternative livelihood activities in Similipal Tiger Reserve, India. Forest Policy and Economics, 73, 215-228. https://doi.org/10.1016/j.forpol.2016.09.012

Davila, F., Bourke, R. M., McWilliam, A., Crimp, S., Robins, L., Van Wensveen, M., ... \& Butler, J. R. (2021). COVID-19 and food systems in Pacific Island Countries, Papua New Guinea, and TimorLeste: Opportunities for actions towards the sustainable development goals. Agricultural Systems, 191, 103137. https://doi.org/10.1016/j.agsy.2021.103137

Derks, J., Giessen, L., \& Winkel, G. (2020). COVID-19-induced visitor boom reveals the importance of forests as critical infrastructure. Forest Policy and Economics, 118, 102253. https://doi.org/10.1016/j. forpol.2020.102253

Dharmiasih, W. (2020). Cultural landscapes in the Asia-Pacific: Re-focusing UNESCO designation on community participation. Forest and Society, 4(2), 271-279. http://dx.doi.org/10.24259/fs.v4i2.10028

Durant, J. L. (2019). Where have all the flowers gone? Honey bee declines and exclusions from floral resources. Journal of Rural Studies, 65, 161-171. https://doi.org/10.1016/j.jrurstud.2018.10.007

El-Nahhal, Y. (2020). Pesticide residues in honey and their potential reproductive toxicity. Science of the Total Environment, 741, 139953. https://doi.org/10.1016/j.scitotenv.2020.139953.

FAO (Food and Agriculture organization). (2015). Forest and proverty reduction. Food and Agriculture Organization of the United Nations. Retrieved from http://www.fao.org/forestry/livelihoods/en/

FAO (Food and Agriculture organization). (2019). Honey. Retrieved from http://www.fao.org/resources/infographics/infographics-details/en/c/1202954/

Gentle, P., Maraseni, T. N., Paudel, D., Dahal, G. R., Kanel, T., \& Pathak, B. (2020). Effectiveness of community forest user groups (CFUGs) in responding to the 2015 earthquakes and COVID-19 in Nepal. Research in Globalization, 2, 100025. http://dx.doi.org/10.1016/j.resglo.2020.100025

Golar, G., Malik, A., Muis, H., Herman, A., Nurudin, N., \& Lukman, L. (2020). The social-economic impact of COVID-19 pandemic: implications for potential forest degradation. Heliyon, 6(10), 1-10. https://doi.org/10.1016/j.heliyon.2020.e05354

Goniewicz, K., Khorram-Manesh, A., Hertelendy, A. J., Goniewicz, M., Naylor, K., \& Burkle, F. M. (2020). Current response and management decisions of the European Union to the COVID-19 outbreak: a review. Sustainability, 12(9), 3838. https://doi.org/10.3390/su12093838

Grabowski, N. T., \& Klein, G. (2017). Microbiology and foodborne pathogens in honey. Critical Reviews in Food Science and Nutrition, 57(9), 1852-1862. https://doi.org/10.1080/10408398.2015.1029041

Hossain, K. S., Hossain, M. G., Moni, A., Rahman, M. M., Rahman, U. H., Alam, M., ... \& Uddin, M. J. (2020). Prospects of honey in fighting against COVID-19: pharmacological insights and therapeutic promises. Heliyon, 6(12), e05798. https://doi.org/10.1016/j.heliyon.2020. e05798

Hussain, J., Zhou, K., Akbar, M., Raza, G., Ali, S., Hussain, A., ... \& Ghulam, A. (2019). Dependence of rural livelihoods on forest resources in Naltar Valley, a dry temperate mountainous region, Pakistan. Global Ecology and Conservation, 20, e00765. https://doi.org/10.1016/j.gecco.2019.e00765

Kibria, A. S., Costanza, R., Groves, C., \& Behie, A. M. (2018). The interactions between livelihood capitals and access of local communities to the forest provisioning services of the Sundarbans Mangrove Forest, Bangladesh. Ecosystem Services, 32, 41-49. https://doi.org/10.1016/j.ecoser.2018.05.003

Koffi, C. K., Gazull, L., \& Gautier, D. (2018). Variability of household fuelwood consumption in a rural Sudano-Sahelian context in Burkina Faso. Energy for Sustainable Development, 47, 75-83. https://doi.org/10.1016/j.esd.2018.09.001

Kovács-Hostyánszki, A., Földesi, R., Báldi, A., Endrédi, A., \& Jordán, F. (2019). The vulnerability of plant-pollinator communities to honeybee decline: A comparative network analysis in 
$\begin{array}{llll}\text { different } \quad \text { habitat } & \text { types. Ecological }\end{array}$ https://doi.org/10.1016/j.ecolind.2018.09.047

Kumar, H., Pandey, B. W., \& Anand, S. (2019). Analyzing the impacts of forest ecosystem services on livelihood security and sustainability: a case study of Jim Corbett National Park in Uttarakhand. International Journal of Geoheritage and Parks, 7(2), 45-55. https://doi.org/10.1016/j.ijgeop.2019.05.003

Laudari, H.K., Pariyar, S., Maraseni, T. (2021). COVID-19 lockdown and the forestry sector: Insight from Gandaki province of Nepal. Forest Policy and Economics, 132, 102556. https://doi.org/10.1016/j.forpol.2021.102556

LGR (Local Government Regulation). (2017). Peraturan Daerah No. 6 Tahun 2017 tentang Pengelolaan Hasil Hutan Bukan Kayu di Provinsi Nusa Tenggara Timur.

LGR (Local Government Regulation). (2020). Peraturan Gubernur No. 36 Tahun 2020 tentang Sentra Pengembangan Madu Mutis di Provinsi Nusa Tenggara Timur

Lee, S. M., Kim, Y. S., Jaung, W., Latifah, S., Afifi, M., \& Fisher, L. A. (2015). Forests, fuelwood and livelihoods-energy transition patterns in eastern Indonesia. Energy Policy, 85, 61-70. https://doi.org/10.1016/j.enpol.2015.04.030

Lima, T. R., Ela, M. Z., Khan, L., Hossain, M. T., Jahan, N., Rahman, K. S., ... \& Islam, M. N. (2021). Livelihood and health vulnerabilities of forest resource-dependent communities amidst the COVID-19 pandemic in southwestern regions of Bangladesh. In Environmental Resilience and Transformation in Times of COVID-19 (pp. 343-356). Elsevier. https://doi.org/10.1016/B9780-323-85512-9.00027-9

Matias, D. M. S., Tambo, J. A., Stellmacher, T., Borgemeister, C., \& von Wehrden, H. (2018). Commercializing traditional non-timber forest products: An integrated value chain analysis of honey from giant honey bees in Palawan, Philippines. Forest Policy and Economics, 97, 223231. https://doi.org/10.1016/j.forpol.2018.10.009

Miller, P., de Barros, A. G., Kattan, L., \& Wirasinghe, S. C. (2017). Managing uncertainty in the application of composite sustainability indicators to transit analysis. Transportation Research Procedia, 25, 4003-4018. https://doi.org/10.1016/j.trpro.2017.05.251

Miyamoto, M. (2020). Poverty reduction saves forests sustainably: Lessons for deforestation policies. World Development, 127, 104746. https://doi.org/10.1016/j.worlddev.2019.104746

Moeliono, M., Thuy, P. T., Bong, I. W., Wong, G. Y., \& Brockhaus, M. (2017). Social Forestry - why and for whom? A comparison of policies in Vietnam and Indonesia. Forest and Society, 1(2), 78-97. http://dx.doi.org/10.24259/fs.v1i2.2484

MoF (Ministry of Forestry). (2007). Peraturan Menteri Kehutanan Nomor 35 Tahun 2007 Tentang Hasil Hutan Bukan Kayu. Retrieved from http://ifccksk.org/documents/documents/regulation/P35_2007_HASIL_HUTAN_BUKAN_KAYU.pdf

Mohan, M., Rue, H. A., Bajaj, S., Galgamuwa, G. P., Adrah, E., Aghai, M. M., ... \& Cardil, A. (2021). Afforestation, reforestation and new challenges from COVID-19: Thirty-three recommendations to support civil society organizations (CSOs). Journal of Environmental Management, 287, 112277. https://doi.org/10.1016/j.jenvman.2021.112277

Mooy, B. Z. (2020). Identifikasi Faktor-Faktor yang Mempengaruhi Dinamika Produksi Madu Lebah Hutan (Apis dorsata) di KDHTK Diklat Sisimeni Sanam, Kabupaten Kupang. Jurnal Widyaiswara Indonesia, 1(4), 171-186.

Moškrič, A., Mole, K., \& Prešern, J. (2021). EPIC markers of the genus Apis as diagnostic tools for detection of honey fraud. Food Control, 121, 107634. https://doi.org/10.1016/j.foodcont.2020.107634

Nagir, M. T., Atmowidi, T., \& Kahono, S. (2016). The distribution and nest-site preference of Apis dorsata binghami at Maros Forest, South Sulawesi, Indonesia. Journal of Insect Biodiversity, 4(23), 1-14. https://doi.org/10.12976/jib/2016.4.23

Nepal, M., Nepal, A. K., \& Berrens, R. P. (2017). Where gathering firewood matters: Proximity and forest management effects in hedonic pricing models for rural Nepal. Journal of Forest Economics, 27, 28-37. https://doi.org/10.1016/j.jfe.2017.02.005 
Nguyen, H.T.L., Panyoyai, N., Paramita, V. D., Mantri, N., \& Kasapis, S. (2018). Physicochemical and viscoelastic properties of honey from medicinal plants. Food Chemistry, 241, 143-149. https://doi.org/10.1016/j.foodchem.2017.08.070

Njurumana, G. N. (2016). Village community and flora biodiversity management in home garden system at central of Sumba regency. Jurnal Penelitian Kehutanan Wallacea, 5(1), 1-12. https://dx.doi.org/10.18330/jwallacea.2016.vol5iss1pp25-36

Njurumana, G. N. (2019). Provision services of biodiversity on Kaliwu agroforest system. Jurnal Pemuliaan Tanaman Hutan, 13(2), 131-140. https://doi.org/10.20886/jpth.2019.13.2.\%p

Njurumana, G. N., Ginoga, K., \& Octavia, D. (2020). Sustaining farmers livelihoods through community forestry in Sikka, East Nusa Tenggara, Indonesia. Biodiversitas Journal of Biological Diversity, 21(8), 3786-3796. https://doi.org/10.13057/biodiv/d210846

Oli, B. N., Treue, T., \& Smith-Hall, C. (2016). The relative importance of community forests, government forests, and private forests for household-level incomes in the Middle Hills of Nepal. Forest Policy and Economics, 70, 155-163. https://doi.org/10.1016/j.forpol.2016.06.026

Oncini, F., Bozzini, E., Forno, F., \& Magnani, N. (2020). Towards food platforms? An analysis of online food provisioning services in Italy. Geoforum, 114, 172-180. https://doi.org/10.1016/j.geoforum.2020.06.004

Paudel, J. (2021). Short-run environmental effects of COVID-19: Evidence from forest fires. World Development, 137, 105120. https://doi.org/10.1016/j.worlddev.2020.105120

Peraturan Gubernur Nusa Tenggara Timur Nomor 36 Tahun 2020 Tentang Sentra Madu Mutis.

Pfefferbaum, B., \& North, C. S. (2020). Mental health and the Covid-19 pandemic. New England Journal of Medicine, 383(6), 510-512. https://doi.org/10.1056/NEJMp2008017

Pujiono, E., Sadono, R., \& Imron, M. A. (2019). Assessment of causes and future deforestation in the mountainous tropical forest of Timor Island, Indonesia. Journal of Mountain Science, 16(10), 2215-2231. https://doi.org/10.1007/s11629-019-5480-1

Sudrajat, D. J., Nurhasybi, N., \& Suita, E. (2018). Comparison of Nyamplung Plant Establishment: Direct Seeding, Bare-root, Blocked Media, and Containerized Seedlings. Jurnal Manajemen Hutan Tropika, 24(2), 51-51. http://dx.doi.org/10.7226/jtfm.24.2.51

Rasmussen, L. V., Watkins, C., \& Agrawal, A. (2017). Forest contributions to livelihoods in changing agriculture-forest landscapes. Forest policy and economics, 84, 1-8. https://doi.org/10.1016/j.forpol.2017.04.010

Riwu Kaho, N.P.L,B., Koenunu., C., \& Nomeni, Y. (2019). Kajian bentang alam Daerah Aliran Sungai kompleks hutan Mutis Timau. Program Kanoppi (CIFOR, WWF, ACIAR, CGIAR).

Riwu Kaho, N.P.L.B., \& Nomeni, Y.F. (2019). Survey Karakteristik Sarang, Pohon Persarangan dan Habitat Lebah Madu Pada Hutan Mutis. Program Kanoppi (CIFOR, WWF, ACIAR, CGIAR)

Rowan, N. J., \& Galanakis, C. M. (2020). Unlocking challenges and opportunities presented by COVID19 pandemic for cross-cutting disruption in agri-food and green deal innovations: Quo Vadis?.Science of the Total Environment, 748, 141362. https://doi.org/10.1016/j.scitotenv.2020.141362

Rowan, N. J., \& Laffey, J. G. (2020). Challenges and solutions for addressing critical shortage of supply chain for personal and protective equipment (PPE) arising from Coronavirus disease (COVID19) pandemic-Case study from the Republic of Ireland. Science of the Total Environment, 725, 138532. https://doi.org/10.1016/j.scitotenv.2020.138532

Saadat, S., Rawtani, D., \& Hussain, C. M. (2020). Environmental perspective of COVID-19. Science of the Total environment, 728, 138870. https://doi.org/10.1016/j.scitotenv.2020.138870

Shammi, M., Bodrud-Doza, M., Islam, A. R. M. T., \& Rahman, M. M. (2020). COVID-19 pandemic, socioeconomic crisis and human stress in resource-limited settings: a case from Bangladesh. Heliyon, 6(5), e04063. https://doi.org/10.1016/j.heliyon.2020.e04063.

Sharma, G. D., \& Mahendru, M. (2020). Lives or livelihood: Insights from locked-down India due to COVID19. Social Sciences \& Humanities Open, 2(1), 100036. https://doi.org/10.1016/j.ssaho.2020.100036

Soares, S., Grazina, L., Mafra, I., Costa, J., Pinto, M. A., Oliveira, M. B. P., \& Amaral, J. S. (2019). Towards honey authentication: Differentiation of Apis mellifera subspecies in European 
honeys based on mitochondrial DNA markers. Food chemistry, 283, 294-301. https://doi.org/10.1016/j.foodchem.2018.12.119

Tamru, S., Hirvonen, K., \& Minten, B. (2020). Impacts of the COVID-19 crisis on vegetable value chains in Ethiopia. In Swinnen, J. \& Mcdermott, J. COVID-19 and global food security (pp. 81 83). International Food Policy Research Institute (IFPRI).

Taylor, M. (2020). Deforestation risks rise as coronavirus hinders SE Asia protection. Retrieved from https://www.reuters.com/article/health-coronavirus-deforestation-idUSL8N2BJ12Z

The Guardian. (2020). Brazil scales back environmental enforcement amid coronavirus outbreak. Retrieved from https://www.theguardian.com/world/2020/Dec/15/brazil-scalesbackenvironmental-enforcement-coronavirus-outbreak-deforestation

Umaya, R., Soekmadi, R., \& Sunito, S. (2020). Direct economic benefits and human dependence toward Gunung Merapi National Park, Indonesia. Biodiversitas Journal of Biological Diversity, 21(3), 982-993. https://doi.org/10.13057/biodiv/d210318

Wahlén, C. B. (2017). Opportunities for making the invisible visible: Towards an improved understanding of the economic contributions of NTFPs. Forest Policy and Economics, 84, 1119. https://doi.org/10.1016/j.forpol.2017.04.006

Wakhidah, A.Z., Chikmawati., \& Purwanto, Y. (2020). Homegarden ethnobotany of two Saibatin villages in Lampung, Indonesia: species diversity, uses, and values. Forest and Society, 4(2), 338-357. https://doi.org/10.24259/fs.v4i2.9720

Wannaprasert, P., \& Choenkwan, S. (2021). Impacts of the COVID-19 pandemic on ginger production: Supply chains, labor, and food security in Northeast Thailand. Forest and Society, 5(1), 120-135. https://doi.org/10.24259/fs.v5i1.11897

Wiratno. (2018). Sepuluh Cara Baru Kelola Kawasan Konservasi di Indonesia: Membangun "Organisasi Pembelajar". Direktorat Jenderal KSDAE, Kementerian Lingkungan Hidup dan Kehutanan Republik Indonesia. Retrieved from http://ksdae.menlhk.go.id/assets/publikasi/10_Cara_Baru\%20Kelola\%20KK.pdf

Workie, E., Mackolil, J., Nyika, J., \& Ramadas, S. (2020). Deciphering the impact of COVID-19 pandemic on food security, agriculture, and livelihoods: A review of the evidence from developing countries. Current Research in Environmental Sustainability, 2, 100014. https://doi.org/10.1016/j.crsust.2020.100014

Woyke, J., Wilde, J., \& Wilde, M. (2012). Swarming and migration of Apis dorsata and Apis laboriosa honey bees in India, Nepal and Bhutan. Journal of Apicultural Science, 56(1), 81-91. http://dx.doi.org/10.2478/v10289-012-0009-7

Zhou, P., Yang, X. L., Wang, X. G., Hu, B., Zhang, L., Zhang, W., ... \& Shi, Z. L. (2020). A pneumonia outbreak associated with a new coronavirus of probable bat origin. Nature, 579(7798), 270273. https://doi.org/10.1038/s41586-020-2012-7 